\title{
Realization of Substantive Law through Legal Proceedings
}

\author{
Ed. by Alexander Bruns and Masabumi Suzuki
}

[Durchsetzung des materiellen Rechts durch Gerichtsverfahren.]

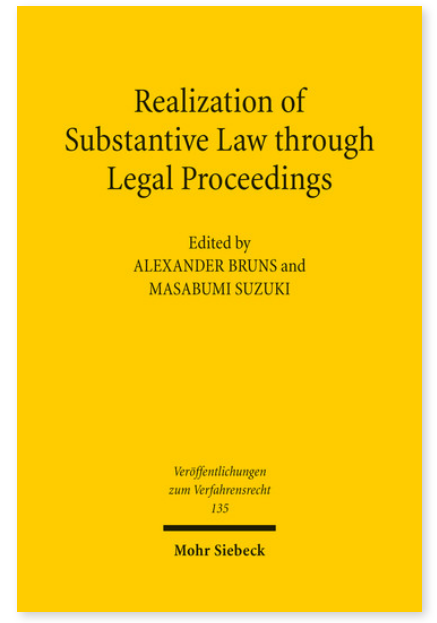

2017. VIII, 119 Seiten. VVerfR 135

ISBN 978-3-16-155231-1

DOI 10.1628/978-3-16-155231-1

eBook PDF 79,00€

ISBN 978-3-16-155230-4

fadengeheftete Broschur 79,00€
Veröffentlicht auf Englisch.

Der Band enthält die Beiträge eines Symposiums, das entsprechend einer Tradition freundschaftlicher Verbundenheit der rechtswissenschaftlichen Fakultäten der Albert-Ludwigs-Universität Freiburg und der Nagoya University vom 30. September 01. Oktober 2015 über das Thema »Realization of Substantive Law through Legal Proceedings« in Nagoya stattgefunden hat. In einer Phase, in der die Bedeutung gerichtlicher Rechtsdurchsetzung zunehmend infrage gestellt wird und der Zeitgeist alternative Verfahren auf breiter Front favorisiert, stellt sich die Frage nach dem Zweck des Zivilprozesses sowie dem Verhältnis von materiellem Recht und verfahrensmäßiger Durchsetzung mit besonderem Nachdruck. Die Thematik betrifft dabei nicht nur das klassische Zivil- und Zivilprozessrecht, sondern wird beispielsweise auch im Bereich des Arbeits- und Patentrechts sowie des internationalen Privatrechts relevant. Der vorliegende Tagungsband reflektiert die rechtsvergleichende Dimension dieses Themas, begegnen doch in Japan und Deutschland gegenwärtig ähnliche Tendenzen und Fragestellungen.

Inhaltsübersicht

\section{Civil Procedure and Civil Law}

Alexander Bruns: Law Enforcement vs. Dispute Resolution. What is the Primary Purpose of Civil Procedure? - Miyuki Watanabe: Dispute Resolution and the Primary Purpose of Civil Procedure in Japan - Tomohiro Yoshimasa: Primary Purpose of Civil Procedure. A Perspective from the Japanese Civil Code

\section{Private International Law}

Jan von Hein: The Determination and Application of Foreign Law. A Blind Spot of European Private International Law? - Dai Yokomizo: Application of Foreign Law in Japanese Courts. Ideal and Reality

\section{Intellectual Property Law}

Maximilian Haedicke: Court-Appointed Technical Experts in German Patent Infringement Proceedings and in the Unified Patent System - Masabumi Suzuki: Pursuit of Pro-Innovation Patent Proceedings. Recent Experience of Japan

Labor Law

Sebastian Krebber: Alternative and Amicable Resolution of Labour and Employment Law Disputes - Hajime Wada: Individual Labor-Related Disputes and ADR in Japan. A Focus on the Labor Tribunal System

Alexander Bruns Geboren 1966; 1996 Promotion; 2002 Habilitation; Direktor des Instituts für deutsches und ausländisches Zivilprozessrecht der Albert-Ludwigs-Universität Freiburg i.Br.

Masabumi Suzuki is Professor, since 2018 Dean of Nagoya University Graduate School of Law, Japan. https://orcid.org/0000-0002-0622-422X

Jetzt bestellen:

https://mohrsiebeck.com/buch/realization-of-substantive-law-through-legal-proceedings-9783161552311?no cache=1 order@mohrsiebeck.com

Telefon: +49 (0)7071-923-17

Telefax: +49 (0)7071-51104 